\title{
KARAKTERISTIK KOMPOSISI KIMIA DAN TOTAL BAKTERI IKAN ROA (Hemirhampus sp.) ASAP YANG DI PASARKAN DI KECAMATAN BUNGKU TENGAH KABUPATEN MOROWALI
}

\author{
Characterstics of Chemical Composition and Total Bacterial of Roa (Hemirhampus sp.) \\ Smoke Marketed in the Bungku District of Central Morowali District \\ Haslianti, Sarni* ${ }^{*}$, Suwarjoyowirayatno \\ Jurusan Teknologi Hasil Perikanan, Fakultas Perikanan dan Ilmu Kelautan Universitas Halu Oleo, Kendari, \\ Sulawesi Tenggara, Indonesia
}

*Email korespondensi: sarnirinythp@gmail.com (Telp: +6285396752388)

Diterima: 10 Januari/ Disetujui 12 Maret 2020

Cara sitasi: Haslianti, Sarni, Suwarjoyowirayatno. 2020. Karakteristik komposisi kimia dan total bakteri ikan roa (Hemirhampus sp.) asap yang di pasarkan di Kecamatan Bungku Tengah Kabupaten Morowali. Jurnal Fish Protech. 3(1):113-119.

\section{ABSTRACT}

The aim of this study was to determine the characteristics of chemical composition (water, ash, protein and fat) and total bacteria (TPC) of smoked roa fish. Data analysis this study used descriptive analysis. The method used study is the survey method (Simple Random Sampling). The results of the chemical composition of the highest treatment water content $P 213.02 \%$, ash P3 5.65\%, protein P3 40.82\%. and fat P3 13.87\%. The best organoleptic test results were found in P1 with 7.30 appearance, 8.20 odor, 8.00 taste, 7.80 texture, and the best mushroom specifications were at $P 29.00$. The best total bacteria test was found in nilai $0,83 \times 10^{5} \mathrm{Log}$ CFU/gr.

Keywords: Ikan roa (Hemirhampus sp.) Asap, Total Plate Count (TPC), Uji Kimia, dan Uji Organoleptik

\begin{abstract}
ABSTRAK
Tujuan penelitian ini adalah untuk mengetahui karakteristik komposisi kimia (kadar air, kadar abu, kadar protein dan kadar lemak) dan total bakteri (TPC) terhadap ikan roa asap. Analisis data yang digunakan dalam penelitian ini yaitu menggunakan analisis deskriptif. Metode yang digunakan dalam penelitian ini yaitu metode survey (Simple Random Sampling). Hasil penelitian komposisi kimia perlakuan tertinggi kadar air P2 13,02\%. Kadar abu tertinggi terdapat pada perlakuan P3 5,65\%. Kadar protein perlakuan tertinggi terdapat pada P3 40,82\%. dan kadar lemak perlakuan tertinggi terdapat pada P3 13,87\%. Hasil penilaian uji organoleptik terbaik terdapat pada P1 sepesifikasi kenampakan 7,30, bau 8,20 , rasa 8,00 , tekstur 7,80 dan pada spesifikasi jamur nilai terbaik terdapat pada P2 9,00. Total bakteri terendah terdapat pada P3 dengan nilai $0,83 \times 10^{5} \mathrm{Log}$ CFU/gr.
\end{abstract}

Kata kunci: Ikan roa (Hemirhampus sp.) Asap, Total Plate Count (TPC),Uji Kimia, dan Uji Organoleptik

\section{PENDAHULUAN}

Potensi ikan roa di Kabupaten Morowali cukup melimpah dan belum dimanfaatkan secara optimal sehingga perlu dilakukan suatu upaya pengembangan dan penganekaragaman produk olahan ikan roa. Salah satu upaya untuk meningkatkan nilai tambah ekonomi ikan roa, dalam rangka upaya tersebut perlu dilakukan upaya diversifikasi maka salah satu cara yang dilakukan masyarakat setempat adalah dengan cara membuat produk ikan roa asap. 
Ikan merupakan bahan pangan yang mudah membusuk, untuk itu diperlukan proses pengolahan dan pengawetan yang bertujuan untuk menghambat bahkan menghentikan aktivitas zat-zat dan mikroorganisme perusak atau enzim-enzim yang dapat menyebabkan kemunduran mutu dan kerusakan (Adawiyah, 2008) dalam (Hasana dan Suyatna, 2015). Salah satu metode pengawetan ikan yang sudah banyak digunakan adalah pengasapan (Ghazali et al., 2014). Oleh karena itu perlu dilakukan usaha untuk meningkatkan daya simpan dan daya awet produk perikanan melalui proses-proses pengolahan maupun pengawetan salah satunya proses pengasapan (Afrianto dan Liviawaty 1991).

Pengasapan merupakan salah satu cara untuk mengawetkan produk agar tidak terjadi pembusukan dan menjaga nilai gizinya. Pengasapan juga berfungsi untuk menambah citarasa dan warna pada makanan serta bertindak sebagai antibakteri dan antioksidan (Adawiyah, 2008) pengawetan tersebut dapat berpengaruh baik oleh mutu maupun daya awet produk yang diasap. Selain itu, cara pengawetan ini pun dapat mempengaruhi mutu dan daya awet mulai dari cara persiapan bahan, jenis asap yang digunakan, kelembaban, kecepatan pengasapan dan suhu pengasapan (Saleh dan Sari, 2007).

Menurut Patty et al.,(2015), usaha pengolahan ikan roa asap yang dilakukan saat ini masih dilakukan dengan teknik yang sederhana dengan menggunakan kayu sebagai bahan bakarnya. Pengolahan ikan secara sederhana otomatis memiliki beberapa kekurangan seperti kurang terjaganya aspek sanitasi pada proses pengolahan. Aspek sanitasi merupakan salah satu yang sangat dipertimbangkan untuk menjamin mutu suatu produk olahan pangan.

\section{METODE PENELITIAN}

\section{Alat dan Bahan}

Alat yang digunakan untuk proses pengasapan yaitu wadah untuk mencuci ikan, anyaman bambu untuk penjepit ikan, batang kelapa, sabut kelapa dan minyak tanah untuk proses pengasapan. pada analisis total mikroba cawan petri (Difco), Tabung raksi (Duran), Pipet volume (Phyrex), Bunsen (Usbeck), Korek api, Incubator (Memmert IN30), Timbangan analitik (Kern), Mortar , Pinset, incubator (Memmert).

Bahan yang digunakan pada penelitian adalah ikan roa (Hemirhampus sp) yang diambil di Kecamatan Bungku Tengah di Kabupaten Morowali Sulawesi Tengah. Bahan analisis yang digunakan yaitu aquades, $\mathrm{HNO}_{3}, \mathrm{HCLO}_{4}$, serbuk $\mathrm{Ca}\left(\mathrm{NO}_{3}\right)_{2}, \mathrm{NaNO}_{3}$, dan $\mathrm{PO}_{4}{ }^{3-}$, asam nitrat $\left(\mathrm{HNO}_{3}\right)$ pekat, dan asam klorida $(\mathrm{HCl})$ pekat.

\section{Metode pengambilan sampel}

Metode yang digunakan dalam penelitian ini yaitu metode survey. Sampel yang akan diambil menggunakan metode sampling acak sederhana (Simple Random Sampling) disertai wawancara. Pengambilan sampel yang dilakukan dari beberapa pasar yang ada di Kecamatan Bungku Tengah yaitu desa Lahuafu (P1), Puungkoilu (P2), dan Bahonto Bungku (P3), tiap Kecamatan sampel yang diambil sebanyak 100 gr dan kemudian dibawa di Laboratorium untuk dilakukan pengujian.

\section{Parameter uji}

Analisis uji kimia meliputi kadar air, kadar abu, kadar protein,dan kadar lemak. Analisis uji organoleptik yang meliputi (Kenampakan, Bau, Rasa, Tekstur, dan Jamur). Analisis uji Total Plate Count (TPC).

\section{Analisis data}

Analisis data penelitian ini menggunakan analisis dekriptif. Analisis deskriptif merupakan analisis yang paling mendasar untuk menggambarkan keadaan data secara umum (Wiyono, 2001). 


\section{HASIL DAN PEMBAHASAN}

Berdasarkan hasil dari penelitian tentang ikan roa asap yang diambil dari Kecamatan Bungku Tengah Kabupaten Morowali. Hasil uji organoleptik, uji kimia, dan Total Plate count (TPC) dapat dilihat pada Tabel berikut

Tabel 1. Hasil hasil analisis uji organoleptik ikan roa asap

\begin{tabular}{lcccc}
\hline \multirow{2}{*}{ Spesifikasi } & Nilai Minumium SNI & \multicolumn{3}{c}{ Kode sampel } \\
\cline { 3 - 5 } & 2009 & P1 & P2 & P3 \\
\hline Kenampakan & 7,00 & 7,30 & 6,70 & 6,80 \\
Bau & 7,00 & 8,20 & 6,80 & 7,30 \\
Rasa & 7,00 & 8,00 & 7,70 & 7,40 \\
Tekstur & 7,00 & 7,80 & 7,10 & 7,70 \\
Jamur & 7,00 & 8,20 & 9,00 & 8,60 \\
\hline
\end{tabular}

Tabel 2. Nilai hasil analisis uji kimia ikan roa asap

\begin{tabular}{lcccc}
\hline & \multicolumn{4}{c}{ Hasil Uji } \\
\cline { 2 - 5 } $\begin{array}{c}\text { Kode } \\
\text { sampel }\end{array}$ & $\begin{array}{c}\text { Kadar } \\
\text { Air }\end{array}$ & $\begin{array}{c}\text { Kadar } \\
\text { Abu }\end{array}$ & $\begin{array}{c}\text { Protein } \\
(\%)\end{array}$ & $\begin{array}{c}\text { Lemak } \\
(\%)\end{array}$ \\
\hline P1 & $(\%)$ & $(\%)$ & 40.31 & 13.69 \\
P2 & 11.78 & 5.37 & 39.54 & 15.08 \\
P3 & 13.02 & 5.40 & 40.82 & 13.87 \\
\hline
\end{tabular}

Tabel 3. Nilai hasil analisis Total Plate count (TPC) ikan roa asap

\begin{tabular}{lll}
\hline Kode & Hasil Uji & Standar SNI 2771: \\
Sampel & (Cfu/gr) & $2009(\text { Cfu/gr })^{*}$ \\
\hline P1 & $1,02 \times 10^{5}$ & $1 \times 10^{5}$ \\
P2 & $1,04 \times 10^{5}$ & $1 \times 10^{5}$ \\
P3 & $0,83 \times 10^{5}$ & $1 \times 10^{5}$ \\
\hline
\end{tabular}

Sumber : *Standar SNI (2009)

\section{Uji Organoleptik \\ Kenampakan}

Hasil nilai organoleptik kenampakan ikan roa asap pada (Tabel 2) bervariasi untuk setiap produsen. Karakteristik kenampakan ikan roa asap dari ketiga pengolah memiliki nilai yang sesuai standar SNI untuk kenampakan adalah 7. Berdasarkan hasil uji organoleptik yang dilakukan pada parameter kenampakan nilai teritingi terdapat pada P3 dengan nilai sebesar 7,30 dan nilai terendah pada nilai sebesar 6,70. Dari hasil uji kenampakan yang tertinggi terdapat pada P3 sebesar 7.30. Hal ini kemungkinan dikarenakan asap yang diserap oleh tubuh ikan bervariasi (tergantung dari jenis bahan bakar yang digunakan) sehingga memungkinkan warna pada permukaan ikan juga berbeda. Selain itu jumlah kadar air juga mempengaruhi nilai kenampakan tersebut, dimana semakin tinggi kadar airnya maka nilai kenampakan semakin rendah. Menurut penelitian Adawiyah (2008) zat-zat kimia yang dihasilkan dari pembakaran bahan bakar dalam proses pengasapan dapat memberikan warna, tergantung pada jenis kayu yang digunakan. Senyawa asam organik dalam asap akan memberikan warna. Fenol formaldehid 
membentuk lapisan damar sehingga produk menjadi mengkilap.

\section{Bau}

Nilai uji analisis organoleptik pada spesifikasi bau nilai yang tertinggi terdapat pada $\mathrm{P} 1$ sebesar 8,20 dan nilai yang terendah yaitu pada $\mathrm{P} 2$ dengan nilai sebesar 6,80 . Tingginya nilai kadar lemak pada P1 diduga karena lama proses pengasapan yang dilakukan. Menurut Mardiana et al (2014) bahwa ikan sembilang asap dengan perlakuan pengasapan yang berbeda menyatakan bahwa ikan asap yang dilakukan dengan lama pengasapan selama 3 jam memiliki nilai tertinggi sebesar 8,3. Lama pengasapan menentukan lamanya interaksi antara ikan sembilang dan asap. Semakin singkatnya waktu pengasapan, maka semakin sedikit pula jumlah partikel asap yang menempel pada ikan asap. Lambongadil et al (2013) menyatakan bahwa ikan japuh asap kering juga memiliki nilai aroma yang berbeda dari setiap pengolah yang diambil dari pengolah di Sulawesi Utara dengan nilai tertinggi adalah 8,53 dan yang terendah adalah 7,93. Hal ini kemungkinan dikarenakan yang dihasilakan dari bahan bakar dan lama proses pengasapan sangat bervariasi sehinggga memungkinkan bau pada ikan juga berbeda. Selain itu jumlah kadar air memepengaruhi nilai bau tersebut, dimana semakin tinggi kadar airnya maka nilai baunya semakin rendah.

\section{Rasa}

Nilai uji analisis organoleptik pada spesifikasi rasa nilai yang tertinggi terdapat kesukaan panelis terhadap nilai rasa ikan roa asap adalah pada P1 sebesar 8,00 sedangkan nilai terendah pada P3 dengan nilai sebesar 7,40 . Perbedaaan nilai panelis dapat disebabkan setiap panelis memiliki tingkat kesukaan yang berbeda terhadap rasa ikan roa asap. Rasa memberikan rangsangan yang kuat terhadap tingkat kesukaan tingkat panelis. Semakin enak/menarik rasa suatu bahan pangan maka dapat menambah cita rasa minat konsumen untuk memilih produk tersebut. Hasil penelitian Lambongadil et al., (2013) terhadap ikan japuh asap kering memiliki nilai yang bervariasi untuk setiap pengolah. Hal ini kemungkian dikarenakan asap yang diserap oleh tubuh ikan sangat bervariasi sehingga memungkinkan rasa pada permukaan ikan juga berbeda. Selain itu jumlah kadar air juga mempengaruhi nilai rasa semakin rendah. Hal ini kemungkinan karena seamakin rendah kadar air maka kandungan asap dalam produk semakin terkosentrasi.

\section{Tekstur}

Hasil dari uji organoleptik terhadap tekstur ikan roa asap menurut penilaian tingkat kesukaan panelis terhadap tekstur ikan roa asap yang tertinggi yaitu pada P1 dengan nilai sebesar 7,80, sedangkan untuk nilai terendah terdapat pada P2 sebesar 7,10. Berdasarkan dari penilaian panelis spesifikasi tekstur untuk ketiga sampel nilai terbaik terapat pada P1 diduga karena pada proses pengasapan suhu yang digunakan lebih baik dan merata. Menurut Estiasih et al., (2011), faktor yang mempengaruhi tekstur produk asap adalah suhu pengasapan. Pada pemakaian suhu pengasapan yang tinggi akan menyebabkan semakin cepat terjadi penggumpalan protein, sehingga tekstur daging menjadi lebih kompak. Nilai organoleptik tekstur ikan roa asap sangat bervariasi dimana pada perbedaan nilai tekstur pada ikan roa asap yang diperoleh kemungkinan dipengaruhi oleh lamanya lama penyimpanan sejak produk ikan roa asap tersebut diolah. Menurut Saleh dan Sari (2007) pada ikan bandeng asap menyatakan bahwa umur simpan ikan dapat di perpanjang samapi 7 hari jika disimpan pada suhu sekitar $10^{\circ} \mathrm{C}$ atau jika dikemas dengan hampa udara (vacuum). Praktek yang bisa dilakukan oleh para pengolah untuk memeperpanjang daya awet ini ialah dengan mengasap ikan asap untuk beberapa saat.

\section{Jamur}

Hasil uji organoleptik jamur yang tertinggi terdapat pada sampel P2 yaitu dengan nilai sebesar 9,00 , sedangkan nilai terendah terdapat pada P1 yaitu dengan nilai sebesar 8,20. Berdasarkan hasil tertinggi pada P2 diindikasi keberadaan jamur yang tidak ada. Hal tersebut didukung oleh penelitian Yusra et al.,(2016), menyatakan Skor 9,00 berarti memiliki spesifikasi keberadaan jamur yang tidak ada. Penilaian panelis secara visual bahwa keberadaan jamur tidak tampak pada sampel. Hal ini diduga karena 
pengasapan cukup efektif dalam menghambat pertumbuhan jamur. Tidak adanya jamur secara visual pada sampel P1, P2 dan P3 dikarenakan penggunaan asap sebagai cara pengawetan terutama dikaitkan dengan sifat-sifat fungsional asap. Menurut Maga (1998), asap memiliki fungsi sebagai antioksidan, antibakteri dan anti jamur. Pengasapan juga menyebabkan berkurangnya kadar air dalam bahan. Hal ini dapat mendukung dalam proses penghambatan pertumbuhan jamur. Winarno (2004) menyatakan bahwa pertumbuhan mikroorganisme tidak pernah terjadi tanpa adanya air. Kadar air sangat berpengaruh terhadap pertumbuhan mikroba seperti jamur.

\section{Uji Kimia}

\section{Kadar Air}

Nilai rerata kadar air ikan roa asap (Tabel 1) menunjukan nilai tertinggi pada sampel P2 sebesar $13,02 \%$ dan sampel yang terendah pada P3 sebesar $11.69 \%$. Tingginya nilai kadar air diduga karena adanya perbedaan pada lama proses pengasapan dari ketiga sampel tersebut. Dimana pada proses pengasapan dari P2 lebih cepat dibandingkan P1 dan P3 dengan waktu pengasapan 12 jam sedangkan pada P2 waktu lama pengasapan sekitar 9 jam. Menurut Harikedua, (2002) menyatakan bahwa semakin lama waktu pengasapan yang dilakukan maka akan semakin rendah kandungan air dalam produk tersebut. Selain itu, semakin besar perbedaan antara suhu media pemanas dengan bahan yang dikeringkan, semakin besar pula kecepatan pindah panas ke dalam bahan pangan, sehingga penguapan air dari bahan akan lebih banyak dan cepat Taib (1987) batas maksimal kadar air dalam ikan asap menurut Standar Nasional Indonesia tahun 2009 adalah 60\%. Berdasarkan hasil uji labolatorium dengan kisaran presentase kadar air sebesar 13,02-11,69 \% dari ketiga sampel tersesbut masih memenuhi standar mutu SNI.

\section{Kadar Abu}

Nilai rerata kadar air ikan roa asap (Tabel 1) menunjukan nilai tertinggi yaitu terdapat pada P3 dengan nilai sebesar 5,65\% sedangkan nilai terendah terdapat pada P1 dengan nilai sebesar $5,40 \%$.
Berdasarkan hasil analisis uji kadar abu tertinggi terdapat pada P3 hal ini diduga karena proses lama pengasapan yang dilakukan sekitar 9 jam dengan suhu $60^{\circ} \mathrm{C}-75^{\circ} \mathrm{C}$. Hal ini didukung oleh peneltian Mardiana et al. (2013) menyatakan presentase kadar abu berkorelasi positif terhadap lamanya pengasapan, hal ini terbukti dari hasil uji coba terhadap ikan sembilang asap dengan lama waktu pengasapan 4 jam dapat menurunkan kadar abu mencapai 1,83\%. Rendahnya kadar abu pada P1 diduga kerena lama waktu proses pengasapan yang digunakan \pm 8 jam. Penelitian ini serupa dengan penilitian (Hasana, 2015) tentang kadar abu ikan baung (Mystus nemurus) asap dengan nilai rerata dari kisaran 5,85\% - 5,18\%.

\section{Kadar Protein}

Nilai rerata kadar air ikan roa asap (Tabel 1) menunjukan nilai tertinggi terdapat pada sampel P3 yaitu dengan nilai 40,82\% dan yang terendah terdapat pada P2 39,54\%. Berdasarkan hasil analisis uji kadar protein nilai terendah terdapat pada P2 hal ini diduga karena suhu yanga digunakan pada proses pengasapan cukup tinggi sehinnga mengakibtkan protein tedenaturasi. Hal ini didukung oleh Swastawati et al., (2012) menyatakan kadar protein dapat menurun karna adanya proses pengolahan, dan terjadinya deanturasi protein selama pemanasan. Ghozali et al., (2004) protein yang terdenaturasi akan mengalami koagulasi apabila dipanasakan pada suhu $50^{\circ} \mathrm{C}$ atau lebih.

\section{Kadar Lemak}

Nilai rerata kadar air ikan roa asap (Tabel 1) menunjukan nilai tertinggi terdapat pada sampel P2 yaitu $15,08 \%$, sedangkan nilai terendah pada sampel P1 13,69\%. Tingginya kadar lemak pada P2 diduga karena suhu yang digunakan pada proses pengasapan tidak telampau tinggi dan jarak sumber panas dengan ikan tidak dekat sehingga kadar lemak tidak mengalami kerusakan. Menurut Swastawati, (2004) apabila jarak antara sumber panas dengan ikan tidak dekat, maka kerusakan lemak akibat panas dapat dikurangi. Rendahnya nilai pada P1 diduga karena disebabkan oleh jarak ikan antara sumber panas agak dekat, sehingga diindikasikan lemak pada ikan mengalami kerusakan. Semakin tinggi suhu dan 
lama pengasapan, menyebabkan penurunan nilai kadar lemak. Mardiana et al., (2014) menyatakan bahwa asap panas mengakibatkan lemak pada daging ikan akan meleleh keluar dan melapisi permukaan ikan. Pemanasan akan mempercepat gerakangerakan molekul lemak, sehingga jarak antara molekul lemak menjadi besar dan akan mempermudah proses pengeluaran lemak (Winarno, 2004).

\section{Analisis Total Plate count (TPC)}

Berdasarkan Tabel 3 rerata nilai hasil uji TPC berkisar antara $1,04 \times 10^{5}-0,83 \times 10^{5}$ Cfu/gr. Hasil tersebut lebih rendah dibanding dengan penelitian Jeujanan et al. (2015), menyatakan rerata nilai TPC pada ikan cakalang asap berkisar $4,1 \times 10^{5}-3 \times 10^{5}$ Cfu/gr. Rendahnya nilai tersebut diduga karena lama proses pengasapan ikan roa 9 jam lebih lama dibanding ikan cakalang 5 jam, serta penanganan setelah proses pengsapan yang kurang baik. Pada penelitian Jeujanan et al. (2015), menyatakan sering ditemukan pengolah kurang memperhatikan faktor kebersihan dalam penanganan ikan setelah pengasapan. Penyimpanan ikan yang tidak terjual dan akan dijual pada hari berikutnya juga masih kurang perhatian akan kebersihan dan keamanan pangan.
Penggunaan wadah, distribusi sampai pemasaran masih berpeluang terjadinya kontaminasi. Berdasarkan standar mutu SNI 2725.1:2009 yaitu maksimum 1,0 $\times 10^{5}$, maka perolehan nilai TPC ikan roa asap yang perdagangkan di Kecamatan Bungku Tengah Kabupaten Morowali masih memenuhi standar tersebut serta masih layak untuk dikonsumsi.

\section{KESIMPULAN}

Berdasarkan hasil dan pembahasan dapat disimpulkan sebagai berikut :

1. Uji organoleptik yang didapatkan dengan rerata nilai kenampakan $7.30-6,70 \%$, bau $8,20-6,80 \%$, rasa $8,00-7,40 \%$, tekstur $7,80-7,10 \%$ dan jamur $9,00-8,20 \%$.

2. Berdasarkan hasil uji proksimat didapatkan rerata nilai pada kadar air 13,02-11,69\% kadar abu 5,65$5,37 \%$, kadar protein $40,82-4031 \%$, kadar lemak $13,87-13,08 \%$.

3. Uji Total Plate Count (TPC) yang dilakukan dengan rerata nilai $0,83 \times 10^{5}-1,02 \times 10^{5} \mathrm{Cfu} / \mathrm{gr}$ masih memenuhi standar SNI yang ditetapkan yaitu maksimal $1 \times 10^{5} \mathrm{Cfu} / \mathrm{gr}$, serta masih aman untuk dikonsumsi.

\section{DAFTAR PUSTAKA}

Adawyah, R. 2008. Pengolahan dan Pengawetan Ikan. PT Bumi Aksara. Jakarta.

Afrianto, E dan Liviawaty.1991. Pengawetan dan Pengolahan Ikan. Yogyakarta : Penerbit Kanisius.

BPS Kabupaten Morowali, 2014. Kabupaten Morwali dalam Angka 2014. BPS Kabupaten Morowali. pp.385.

Estiasih T, Ahmadi. 2011. Teknologi Pengolahan Pangan. Bumi Aksara: Jakarta.

Ghazali, R.R., Swastawati, F. \& Ramadhon. 2014. Analisa Tingkat Keamanan Ikan Manyung (Arius thalassinus) Asap Yang Diolah Dengan Metode Pengasapan Berbeda. Program Studi Teknologi Hasil Perikanan, Jurusan Perikanan, Fakultas Perikanan dan IImu Kelautan. Universitas Diponegoro. Semarang.
Ghozali, Thomas., Dedi Muchtadi., Yaroh. 2004. Peningkatan Daya Simpan Sate Bandeng (Chanos chanos) dengan cara Penyimpanan Dingin dan Pembekuan. Imformatek, Vol 6 Nomor1. Bandung.105-110.

Harikedua, J. W. 2002. Metode Analisis Kimia Hasil Perikanan. Penuntun Praktikum. Fakultas Perikanan. UNSRAT. Manado.

Hasana, R. dan Suyatna, I. 2015. Karakteristik Mutu Produk lkan Baung (Mystus nemurus) Asap Industri Rumah Tangga dari Tiga Kecamatan Kutai Barat, Kutai Kartanegara. Jurnal Akuatika. 6 (2) : 170-176.

Jeujanan, Samuel, ljong, Frans G, Onibala, Hens, \& Mentang, Feny. (2015). Organoleptic quality and TPC of smoked skipjack tuna (Katsuwonus pelamis, L) in Jayapura, Papua. AQUATIC SCIENCE \& 
MANEGEMENT (Jurnal IImu dan Manajemen Perairan) , 3 (1), 26-31.

Lambongadil, G.P., Reo, A.R \& Onibala, H. 2013. Studi Mutu Produk Ikan Japuh (Dussumieria acuta C.V.) Asap Kering Industri Rumah Tangga Di Desa Tumpaan Baru Kecamatan Tumpaan. Fakultas Perikanan dan IImu Kelautan. Universitas Samratulangi. Sulawesi Utara. Manado. Jurnal Media Teknologi Hasil Perikanan. $1(2): 12-18$

Maga JA. 1998. Smoke in Food Processing. CRD Press: Florida. USA. Pasir Sakti Lampung Timur. Jurnal Teknik Perikanan Lampung. 5. (3):283-290.

Mardiana, N., Waluyo, S., Ali, M. 2014. Analisis kualitas ikan sembilang (Paraplotosus albilaris) asap dikelompok pengolahan ikan "mina mulya" kecamatan pasir sakti lampung timur. Jurnal Teknik Pertanian Lampung. 3. (3):283-290.

Patty NCh, Dotulong V, Suwetja IK. 2015. Mutu Ikan Roa (Hemirhamphus sp) Asap yang Ada di Pasar Tradisional di Kota Manado yang Disimpan pada Suhu Ruang. Jurnal Media Teknologi Hasil Perikanan. 3(2):45-54.

Saleh, M. dan Sari, A 2007. Kumpulan hasil-hasil Penelitian Pascapenen Perikanan. Balai besar Riset Pengolahan Produk dan Bioteknologi Kelautan dan Perikanan. Jakarta. $313 \mathrm{Hal}$.

SNI 2725.1-2009. Ikan Asap - Bagian 1: Spesifikasi. Pusat Standarisasi Industri. Departemen Industri: Jakarta.

Swastawati F, Surti T, Agustini TW, Riyadi PH. 2013. Karakteristik kualitas ikan asap yang diproses menggunakan metode dan jenis ikan berbeda. Jurnal Aplikasi Teknologi Pangan. 2(3):126-132.

Swastawati, F. Eko S., Bambang, C \& Wahyu, A.J. 2012. Sensory Evaluation and Chemical Charesteric of Smoked Stingray (Dasyatis bleekery) Processed by Using Two Different Liquid Smoke. International Journal of Bioscience, Biochemistry and Biofarmatics. 2 (3):212-216.

Taib, G., G. Said dan S. Wiraatmadja. 1987. Operasi Pengeringan Pada Hasil Pertanian. Medyatama Perkasa. Jakarta

Winarno FG. 2004. Kimia Pangan dan Gizi. PT. Gramedia Pustaka Utama: Jakarta.

Wiyono ,B.2001. Statistik pendidikan: Buku Bahan Ajar Mata Kuliah Statistik. Malang: FIB UM.

Yusra, Efendi Y. 2010. Dasar-Dasar Teknologi Hasil Perikanan. Bung Hatta University Press, Padang. 